\title{
Analisis Determinan Perubahan Laba Bersih Pada Bank Umum Konvensional Di Indonesia Periode 2011-2015
}

\author{
Liga Febriani $^{1}$, Ana Mufidah ${ }^{2}$, Sumani $^{3}$ \\ Fakultas Ekonomi dan Bisnis Universitas Jember ${ }^{1,2,3}$
}

\begin{abstract}
The financial performance of the bank describes the financial condition of banks in a given period. The financial performance of bank can be categorized by looking at a bank's net profit change. Net profit change used by user of financial statements to determine whether there is an increase or decrease in profit, so it can be used as a guide for future managerial decisions. The purpose of this study was to: (1) analyze the NPL is a determinant of commercial bank's net profit change in Indonesia, (2) analyze the IRR is a determinant of commercial bank's net profit change in Indonesia, (3) analyze the LDR is a determinant of commercial bank's net profit change in Indonesia, (4) analyze the ROA is a determinant of commercial bank's net profit change in Indonesia, (5) analyze the NIM is a determinant of commercial bank's net profit change in Indonesia, (6) analyze the BOPO is a determinant of commercial bank's net profit change in Indonesia, (7) analyze the CAR is a determinant of commercial bank's net profit change in Indonesia. Data used in this research is secondary data. The population in this study is the banks listed on the Indonesia Bank in the period 2011-2015. Taking the number of samples by purposive sampling method used multiple linear regression analysis. The test results and data analysis were performed with SPSS 21 showed that: NPL, IRR, ROA, and NIM are determinant of commercial bank's net profit change in Indonesia; $L D R, B O P O$, and CAR ratio are not determinant of commercial bank's net profit change in Indonesia.
\end{abstract}

Keywords : Financial Performance, Profit Change, Non Performing Loan

\section{Pendahuluan}

Bank sebagai lembaga keuangan mempunyai peranan penting dalam suatu perekonomian. Bank mampu memberikan dukungan dalam pembangunan ekonomi dan mendorong pertumbuhan ekonomi di suatu negara. Peran bank dalam pembangunan ekonomi, yaitu bank mampu memberikan dukungan dana bagi perkembangan dunia usaha dengan menjalankan fungsi intermediasi antara unit ekonomi yang surplus kepada unit-unit ekonomi yang membutuhkan dana atau defisit. Perkembangan dunia usaha dapat mendorong pertumbuhan ekonomi, mengurangi pengangguran dan kemiskinan. Fungsi intermediasi ini akan berjalan 
baik apabila pihak surplus dan defisit memiliki kepercayaan kepada bank.

Menurut Undang-Undang Negara Republik Indonesia Nomor 10 Tahun 1998 tentang Perbankan, yang dimaksud dengan bank adalah badan usaha yang menghimpun dana dari masyarakat dalam bentuk simpanan dan menyalurkannya kepada masyarakat dalam bentuk kredit dan atau bentuk lainnya dalam rangka meningkatkan taraf hidup rakyat banyak. Bank umum konvensional adalah bank yang melaksanakan kegiatan usaha berdasarkan prinsip konvensional yang dalam kegiatannya memberikan jasa dalam lalu lintas pembayaran. Penilaian terhadap kinerja suatu bank dapat dilakukan dengan melakukan analisis terhadap laporan keuangan bank. Laporan keungan bank merupakan salah satu sumber utama indikator yang dapat dijadikan dasar penilaian kinerja keuangan bank yang memiliki tujuan utama untuk memberikan informasi yang relevan pada pihakpihak di luar perusahaan. Kinerja keuangan bank adalah penelitian ukuran-ukuran tertentu yang dapat mengukur keberhasilan suatu bank dalam menghasilkan laba. Laba adalah perbedaan pendapatan dengan beban, jikalau pendapatan melebihi beban maka hasilnya adalah laba bersih (Henry, 2002:25). Laba bersih adalah laba operasi dikurangi pajak, biaya bunga, biaya riset dan biaya pengembangan. Laba bersih disajikan dalam laporan laba-rugi dengan menyandingkan antara pendapatan dengan biaya (Hansen and Mowen, 2001:38).

Perubahan laba merupakan besarnya kenaikan atau penurunan laba per tahun (Herlina dan Nur, 2014). Perubahan laba yang terus meningkat atau dengan kata lain perubahan laba yang tinggi dapat berdampak pada aktivitas operasional bank karena mampu memperkuat modal sehingga bank mampu meningkatkan kinerja perusahaannya dengan meningkatkan laba. Para stakeholders memerlukan informasi perubahan laba sebagai pertimbangan pengambilan keputusan. Perubahan laba dapat menjadi signal untuk mengetahui informasi tentang kesempatan yang dapat diraih oleh perbankan dimasa yang akan datang. Rasio Perubahan laba bersih bank umum konvensional di Indonesia periode 2011-2015 cenderung mengalami penurunan dengan nilai presentase setiap tahun sebesar 31,00\%; 23,65\%; 14,95\%; 5,11\% sedangkan tahun 2015 nilai persentase perubahan laba bersih sebesar -7,28 \% (Statistik Perbankan Indonesia, 2015). 
Pada umumnya untuk menganalisis dan menilai kondisi keuangan perbankan mengacu pada metode RGEC (Risk Profile, GCG, Earning, Capital) berbasis pada risiko yang diproksikan dalam berbagai rasio keuangan perbankan. Penelitian perubahan laba bersih dengan menganalisis rasio keuangan bank dapat dilakukan dengan memerhatikan rasio-rasio Non Performing Loan (NPL), Interest Rate Risk (IRR), Loan to Deposit Ratio (LDR), Return on Assets (ROA), Net Interest Margin (NIM), Biaya Operasional terhadap Pendapatan Operasional (BOPO), dan Capital Adequacy Ratio (CAR).

Non Performing Loan (NPL) merupakan rasio yang dipergunakan untuk mengukur kemampuan bank dalam mengkover risiko pengembalian kredit oleh debitur. Rasio NPL dapat dihitung dengan memperbandingkan antara kredit bermasalah terhadap total kredit. NPL merupakan kredit bermasalah yang terdiri dari kredit yang berklasifikasi Kurang Lancar, Diragukan dan Macet (Dahlan, 2005:358).

Interest Rate Risk (IRR) adalah risiko yang dialami akibat adanya perubahan suku bunga yang terjadi di pasar yang mampu memberi pengaruh negatif terhadap pendapatan bank. IRR merupakan rasio yang menunjukkan kemampuan bank mengelola risiko dari adanya perubahan suku bunga (Veithzal Rivai dkk, 2013:570).

Loan to Deposit Ratio (LDR) adalah rasio yang menunjukkan tingkat likuiditas suatu bank dan kemampuan menjalankan fungsi intermediasinya dalam menyalurkan dana pihak ketiga dalam bentuk kredit. Likuiditas adalah kemampuan sebuah bank untuk membayar seluruh kewajiban-kewajibannya dengan seluruh dana yang ada. Rasio ini menilai likuiditas bank dengan cara membagi jumlah kredit yang diberikan oleh bank terhadap dana pihak ketiga (Slamet, 2006: 195).

Return on Assets (ROA) merupakan rasio yang digunakan untuk mengukur kemampuan manajemen bank dalam memperoleh pendapatan dari penggunaan aktiva produktif oleh bank. Semakin besar ROA, semakin besar pula tingkat keuntungan (laba) yang dicapai bank (Lukman, 2009:146).

Net Interest Margin (NIM) merupakan rasio yang digunakan untuk 
menilai kemampuan manajemen bank dalam mengelola aktiva produktifnya untuk menghasilkan pendapatan bunga bersih. Pendapatan diperoleh dari bunga yang diterima dari pinjaman yang diberikan dikurangi dengan biaya bunga dari sumber dana yang dikumpulkan. NIM merupakan perbandingan antara pendapatan bunga bersih terhadap rata-rata aktiva produktif (Slamet, 2006:21).

Biaya Operasional terhadap Pendapatan Operasional (BOPO) adalah rasio perbandingan antara biaya operasional dengan pendapatan operasional. Semakin besar BOPO maka akan semakin kecil atau menurun kinerja keuangan perbankan. Begitu juga sebaliknya, jika BOPO semakin kecil, maka dapat disimpulkan bahwa kinerja keuangan perbankan semakin meningkat atau membaik. Rasio BOPO digunakan untuk mengukur tingkat efisiensi dan kemampuan bank dalam melakukan kegiatan operasinya (Slamet, 2006:159).

Capital Adequacy Ratio (CAR) adalah rasio kinerja bank untuk mengukur kecukupan modal yang dimiliki bank untuk menunjang aktiva yang mengandung atau menghasilkan risiko, misalnya kredit yang diberikan. CAR merupakan indikator terhadap kemampuan bank untuk menutupi penurunan aktivanya sebagai akibat dari kerugian-kerugian bank yang disebabkan oleh aktiva yang berisiko (kredit, penyertaan, surat berharga, tagihan pada bank lain) (Lukman, 2009:144).

\section{Metodologi Penelitian}

Penelitian ini adalah penelitian kuantitatif untuk menganalisis determinan perubahan laba bersih pada bank umum konvensional di Indonesia. Populasi dalam penelitian ini adalah seluruh bank umum konvensional yang terdaftar di Bank Indonesia. Alat analisis yang digunakan adalah regresi linear berganda. Pengambilan sampel dalam penelitian ini dilakukan dengan menggunakan teknik purposive sampling. Dengan kriteria sebagai berikut:

1. Bank umum konvensional yang memiliki laporan keuangan secara lengkap selama tahun 2011-2015

2. Bank umum konvensional yang memperoleh laba selama tahun 20112015.

Penelitian ini menggunakan data sekunder berupa data laporan keuangan (laporan neraca dan laporan laba/rugi) tahunan bank umum konvensional tahun 2010- 
2015 yang diperoleh melalui Publikasi Bank Indonesia dan Otoritas JasaKeuangan.

a. Variabel dependen dalam penelitian ini adalah perubahan laba bersih, yang diproksikan dengan :

$$
\Delta Y_{i t}=\frac{\left(Y_{i t}\right)-\left(Y_{i t-1}\right)}{\left(Y_{i t-1}\right)}
$$

Keterangan :

$\Delta \mathrm{Y}_{\text {it }}=$ perubahan laba bersih bank umum konvensional pada periode $\mathrm{t}$

$Y_{\text {it }}=$ laba Bank" i" pada periode " $t$ "

$Y_{i t-1}=$ laba Bank " $i$ " pada periode " $t$ " - 1

b. Variabel independen :

b.1.Non Performing Loan

$$
\text { NPL }=\frac{\text { Kredit bermasalah }}{\text { total kredit }} \times 100 \%
$$

Sumber: SE BI 13/24/DPNP/2011

b.2.Interset Rate Risk (IRR)

$$
\begin{aligned}
& \mathrm{IRR}=\frac{\text { Interest sensitivity asset }}{\text { Interest sensitivity liabilitie }} \times 100 \% \\
& \text { Sumber : SE BI 13/24/DPNP/2011 }
\end{aligned}
$$

\section{b.3.Loan to Deposit Ratio}

\section{Loan to Deposit Ratio}

$\mathrm{LDR}=\quad \times 100 \%$

Sumber: SE BI 13/24/DPNP/2011

b.4.Return On Asset (ROA)

ROA $=\frac{\text { Laba Sebelum Pajak }}{\text { Rata-rata total asset }} \quad$ X 100\%

Sumber: SE BI 12/11/DPNP/2010

b.5. Net Interest Margin (NIM)

$\mathrm{NIM}=\frac{\text { Pendapatan bunga bersih }}{\text { Rata-rata aktive produktif }} \quad \mathrm{X} 100 \%$

Sumber: SE BI 13/24/DPNP/2011 
b.6. Biaya Operasional terhadap pendapatan Operasional

Beban Operasional

$$
\begin{aligned}
& \text { BOPO }=\frac{\text { Pendapatan Operasional }}{\text { S } 100 \%} \text {. } \\
& \text { Sumber: SE BI 12/11/DPNP/2010 }
\end{aligned}
$$

b.7. Capital Adequacy Ratio (CAR)

Modal Sendiri

$\mathrm{CAR}=\frac{\mathrm{X}}{\text { Aktiva Tertimbang Menurut resiko (AI MK) }}$
Sumber : SE BI $13 / 24 /$ DPNP/2010

3. Hasil dan Pembahasan

Hasil uji t disajikan pada Tabel berikut:

Tabel 1. Hasil Uji T

\begin{tabular}{|l|l|c|c|}
\hline $\mathbf{N}$ & Variabel Independen & Koefisien & $\boldsymbol{p}$-value \\
\hline \multirow{4}{*}{$\mathbf{4 1 0}$} & NPL & $-0,112$ & 0,0165 \\
\cline { 2 - 4 } & IRR & $-0,189$ & 0,0010 \\
\cline { 2 - 4 } & LDR & 0,024 & 0,3315 \\
\cline { 2 - 4 } & ROA & 0,127 & 0,0380 \\
\cline { 2 - 4 } & NIM & 0,129 & 0,0205 \\
\cline { 2 - 4 } & BOPO & $-0,013$ & 0,4125 \\
\cline { 2 - 4 } & CAR & 0,100 & 0,0500 \\
\hline
\end{tabular}

Sumber: Data diolah

Berdasarkan data yang independen ada padaTabe4.10, nilai $p$-value variabel NPL, IRR, ROA, dan NIM lebih kecil nilai signifikansi 5\% yang berarti $\mathrm{H}_{0}$ ditolak, dengan kata lain variabel NPL, IRR, ROA, dan NIM merupakan determinan signifikan perubahan laba bersih bank umum konvensional di Indonesia periode 2011-2015. Sedangkan variabel LDR, BOPO, dan CAR bukan determinan perubahan laba bersih bank umum konvensional di Indonesia periode 2011-2015.

\section{NPL determinan perubahan laba bersih}

Berdasarkan hasil pengujian data diketahui variabel NPL merupakan determinan perubahan laba bersih Bank Umum Konvensional. NPL berpengaruh negatif dan signifikan artinya peningkatan atau penurunan kemampuan suatu bank dalam mengelola kredit bermasalah berpengaruh terhadap tingkat perubahan bank umum konvensional di masa yang akan datang. 
Koefisien NPL bernilai negatif mengindikasikan bahwa semakin besar NPL maka perubahan laba bersih yang diperoleh akan semakin kecil. Peningkatan NPL akan mempengaruhi perubahan laba bersih, karena semakin tinggi NPL maka akan semakin buruk kualitas kredit bank yang menyebabkan jumlah kredit bermasalah semakin besar, dan oleh karena itu bank harus menanggung kerugian dalam kegiatan operasionalnya sehingga berpengaruh terhadap perubahan laba bersih bank umum konvensional. Dengan kata lain bahwa ketika NPL tinggi maka tingkat laba ditahan bank juga ikut tinggi sehingga akan mengakibatkan pendapatan turun dan berdampak juga terhadap penurunan perubahan laba. NPL yang rendah mengindikasikan kinerja keuangan bank semakin baik.

\section{IRR determinan perubahan laba bersih}

Hasil penelitian menunjukkan bahwa variabel IRR merupakan determinan perubahan laba bank umum konvensional. Tanda negatif pada koefisien variabel IRR menunjukkan bahwa kenaikan nilai IRR, tidak diikuti oleh kenaikan nilai perubahan laba. Hal ini terjadi karena persaingan suku bunga yang semakin ketat dalam dunia perbankan di Indonesia yang membuat bank umum konvensional cenderung menawarkan bunga kredit yang hampir sama, dengan penyesuaian suku bunga yang dikeluarkan oleh Bank Indonesia. Akibatnya bank umum konvensional tidak dapat mengambil kebijakan untuk meningkatkan bunga kredit diatas rata-rata karena calon debitur akan beralih ke bank umum konvensional dengan bunga kredit yang lebih rendah, sehingga pendapatan bunga yang diperoleh dari kredit kecil yang menyebabkan perubahan laba menurun.

\section{LDR determinan perubahan laba bersih}

Hasil penelitian menunjukkan bahwa LDR bukan determinan perubahan laba bank umum konvensional. Tidak signifikannya LDR terhadap perubahan laba karena pendapatan bank umum konvensional tidak hanya diperoleh dari pendapatan bunga pinjaman yang diberikan, tetapi juga dihasilkan dari pendapatan berbasis komisi. Perbankan sudah mulai berpindah dari hanya fokus untuk mendapatkan pendapatan yang berasal dari bunga kredit ke fee based income, karena kenyataannya pada saat ini nasabah membutuhkan kemudahan dalam transaksi, asuransi, dan investasi (bisnis.com,2013). Dengan demikian 
pendapatan bunga kredit bukan satunya-satunya sumber pendapatan bank, sehingga LDR tidak berpengaruh banyak terhadap perubahan laba bank umum konvensional.

\section{ROA determinan perubahan laba bersih}

Hasil penelitian menunjukkan bahwa variabel ROA merupakan determinan perubahan laba bank umum konvensional. ROA berpengaruh positif dan signifikan artinya peningkatan atau penurunan kemampuan suatu bank dalam mengelola aktiva produktifnya untuk menghasilkan pendapatan berpengaruh terhadap tingkat perubahan bank umum konvensional di masa yang akan datang.

Adanya pengaruh positif antara ROA dengan perubahan laba menunjukkan bahwa setiap peningkatan nilai ROA pada umumnya akan menyebabkan meningkatnya laba bagi bank umum konvensional, artinya meningkatnya kemampuan perusahaan untuk menghasilkan laba akan menjamin bahwa perubahan laba bank umum konvensional akan meningkat karena ROA merupakan rasio yang menunjukkan seberapa efektifnya bank beroperasi sehingga menghasilkan keuntungan/laba bagi bank umum konvensional.

\section{NIM determinan perubahan laba bersih}

Hasil penelitian menunjukkan bahwa variabel NIM merupakan determinan perubahan laba bank umum konvensional. Hasil penelitian ini menunjukkan bahwa kemampuan manajemen bank umum konvensional dalam mengelola aset produktif untuk menghasilkan pendapatan bunga bersih semakin besar. Semakin besar NIM menunjukkan semakin efektif bank dalam mengelola aktiva produktifnya, sehingga semakin besar pendapatan bunga yang diperoleh dan berpengaruh terhadap peningkatan perubahan laba atau dengan kata lain, Semakin besar NIM semakin besar pula perubahan laba bersih bank umum konvensional sehingga NIM berpengaruh positif terhadap perubahan laba.

\section{BOPO determinan perubahan laba bersih}

Hasil penelitian menunjukkan bahwa variabel BOPO bukan determinan perubahan laba bank umum konvensional. BOPO tidak berpengaruh secara signifikan terhadap perubahan laba. Kondisi ini terjadi karena peningkatan biaya operasional bank yang tidak dibarengi dengan pendapatan operasional yang 
lebih besar. Hal ini ditunjukan dengan rendahnya nilai kredit, sehingga menurunkan pendapatan bunga. Rendahnya kredit disebabkan oleh bank umum konvensional yang lebih memilih untuk menginvestasikan dananya pada investasi dengan risiko yang lebih rendah dibandingkan kredit, yaitu SBI, sehingga pendapatan yang diperolehpun lebih rendah dibandingkan pendapatan bunga yang diperoleh dari kredit yang disalurkan. Ketika bank tidak mampu memperoleh pendapatan yang lebih besar sebagai akibat berinvestasi pada investasi dengan risiko yang lebih rendah membuat pendapatan yang diterima hanya mampu menutupi biaya operasional yang ada dan tidak berpengaruh banyak terhadap perubahan laba.

\section{CAR determinan perubahan laba bersih}

Hasil penelitian menunjukkan bahwa variabel CAR bukan determinan perubahan laba bank umum konvensional. Nilai CAR diperoleh dari modal sendiri bank dibanding dengan ATMR (Aktiva Tertimbang Menurut Risiko), semakin besar ATMR akan menurunkan nilai CAR. Tidak signifikannya CAR terhadap perubahan laba karena adanya peraturan Bank Indonesia yang mensyaratkan CAR minimal sebesar $8 \%$ mengakibatkan bank umum konvensional selalu berusaha menjaga agar CAR yang dimiliki sesuai dengan ketentuan, sehingga bank menginvestasikan dananya dengan hati-hati dan lebih menekankan pada kelangsungan hidup bank umum konvensional. Hal ini ditunjukkan dengan kurangnya penyaluran kredit oleh bank umum konvensional dan lebih memilih untuk membeli SBI dengan risiko yang lebih kecil, yaitu 0. Sehingga nilai ATMR rendah dan nilai CAR tetap besar. Nilai CAR yang besar ini tidak berpengaruh terhadap perubahan laba bank umum konvensional.

\section{Kesimpulan}

Hasil penelitian yang dilakukan dengan bantuan software SPSS 21 menunjukkan bahwa: rasio NPL, IRR, ROA, NIM merupakan determinan perubahan laba bersih bank umum konvensional; rasio LDR, BOPO, dan CAR bukan determinan perubahan laba bersih bank umum konvensional. 


\section{DAFTAR PUSTAKA}

Abdul Rochman dan Kesi Wijajanti. 2011. Analisis Faktor-Faktor yang Mempengaruhi Perubahan Laba Bank. Jurnal Q-MAN. Vol. 2, No. 6:6580 .

Aditya Kusumaningtyas. 2009. “Analisis Pengaruh Rasio Keuangan Terhadap Perubahan Laba (Studi Empiris Pada Perusahaan Perbankan yang Terdaftar di Bursa Efek Indonesia)". Tidak Dipublikasikan. Skripsi. Surakarta: Universitas Muhammadiyah surakarta.

Andra Rizkita. 2012. Analisis Pengaruh CAR, BOPO, NIM, NPL dan LDR Terhadap Perubahan Laba Perbankan yang Terdaftar diBEI. Diponegoro Journal of Management. Vol. 1 No.2: 49-57.

Angbazo, L. 1997. Commercial Bank Net Interest Margin, Default Risk, Interest RateRisk, and Off-Balance Sheet Banking. Journal of Banking and Finance. 21:55-87.

Dahlan Siamat. 2005. Manajemen Lembaga Keuangan. Jakarta: Fakultas Ekonomi Universitas Indonesia.

Hans Kartikahadi, Rosita Uli Sinaga, Syamsul Merliyana \& Sylvia Veronica .2012. Akuntansi Keuangan berdasarkan SAK berbasis IFRS. Jakarta: Salemba Empat.

Hansen, Don. R. dan M. Mowen, Mayane.2001. Manajemen Biasa Akuntansi dan Pengendalian. Buku Dua. Edisi Kesatu. Jakarta: Salemba Empat

Herlina Fitry Karuniawati dan Nur Handayani. 2014. Pengaruh Rasio Keuangan Terhadap Perubahan Laba Pada Bank Bca Darmo Surabaya. Jurnal Ilmu \& Riset Akuntansi.Vol. 3 No. 1 